\title{
PENGEMBANGAN MEDIA PEMBELAJARAN INTERAKTIF KIMIA KOLOID BERBANTUAN KOMPUTER UNTUK SISWA SMA
}

\author{
I Ketut Gede Padmanaba ${ }^{1 *}$, I Made Kirna², I.B. Nyoman Sudria ${ }^{3}$ \\ 1, Universitas Pendidikan Ganesha, Indonesia
}

\author{
A R T I C L E I N F O \\ Article history: \\ Received 19 Oktober 2017 \\ Received in revised form \\ 8 September 2017 \\ Accepted 12 Januari 2018 \\ Available online 31 April \\ 2018 \\ Kata Kunci: \\ Media pembelajaran \\ interaktif, kimia koloid
}

\begin{abstract}
A B S T R A K
Penelitian ini merupakan penelitian pengembangan yang bertujuan untuk menghasilkan produk berupa media pembelajaran interaktif kimia koloid berbantuan komputer untuk siswa SMA. Penelitian pengembangan ini terdiri dari dua tahap pokok, yaitu 1) tahap pembuatan prototipe multimedia pembelajaran interaktif (tahap I), serta 2) tahap validasi dan uji coba produk (tahap II). Tahap pembuatan prototipe multimedia pembelajaran interaktif menggunakan model pengembangan menurut Luther yang terdiri dari tahap concept, design, meterial collecting, assembly, testing dan distribution. Validasi dan uji coba produk merujuk pada evaluasi formatif yang terdapat pada model pengembangan Dick and Carey. Subjek pada tahap validasi meliputi 1 orang dosen sebagai ahli isi, 1 orang dosen sebagai ahli media, 1 orang guru selaku praktisi, serta 3 orang siswa untuk uji coba perorangan dan 20 orang siswa untuk uji kelompok kecil.
\end{abstract} Berdasarkan hasil penilaian oleh ahli isi, media pembelajaran interaktif sistem koloid mendapat skor rata-rata 4,76 atau tergolong ke dalam kriteria sangat baik. Sementara itu, hasil validasi oleh ahli media dan praktisi masing-masing memperoleh skor rata-rata 4,19 dan 3,82 dimana tergolong ke dalam kriteria baik. Berdasarkan hasil uji coba produk yang dilakukan, baik uji perorangan maupun uji kelompok kecil dapat dinyatakan bahwa media pembelajaran kimia interaktif sistem koloid mendapat dukungan positif dari siswa.

\section{Pendahuluan}

Sistem koloid merupakan salah satu materi pelajaran kimia yang diajarkan di SMA kelas XI semester 2. Sesuai dengan Peraturan Menteri Pendidikan Nasional No. 22 Tahun 2006 tentang Standar Isi, pokok bahasan sistem koloid di SMA terdiri dari satu Standar Kompetensi (SK) yakni menjelaskan sistem dan sifat koloid serta penerapannya dalam kehidupan sehari-hari. Standar Kompetensi tersebut terdiri dari dua Kompetensi Dasar (KD) yaitu pembuatan berbagai jenis sistem koloid dengan bahan di sekitar serta pemahaman akan pengelompokkan dan penerapan sistem koloid dalam kehidupan sehari-hari. Sesuai dengan Standar Kompetensi dan Kompetensi Dasarnya pembelajaran sistem koloid di SMA meliputi pengetahuan/konsep (aspek mikroskopik dan simbolik) dan secara eksperimen/praktikum di laboratorium (aspek mekroskopiknya). Dengan adanya kegiatan praktikum maka teori-teori yang telah dipelajari sebelumnya dapat dibuktikan kebenarannya oleh siswa.

Permasalahan yang sering muncul di SMA dalam mengajarkan materi ini adalah kesulitan guru di dalam menyampaikan aspek mikroskopik, makroskopik dan simbolik kepada siswa. Metode ceramah yang umumnya digunakan guru dalam mengajar menyebabkan pemahaman konsep siswa tentang materi yang diajarkan menjadi lemah. Selain itu, dengan metode ceramah dapat menimbulkan berbagai persepsi pada siswa dalam menangkap penyampaian guru. Dalam artian, tidak terjadi kesatuan persepsi dari siswa terhadap materi yang diajarkan.

Hakikat ilmu kimia yang dipandang sebagai proses dan produk hendaknya diterapkan dalam mengajarkan materi sistem koloid kepada siswa. Kimia sebagai proses meliputi keterampilanketerampilan dan sikap-sikap yang dimiliki untuk memperoleh dan mengembangkan pengetahuan. Sementara itu, kimia sebagai produk meliputi sekumpulan pengetahuan yang terdiri atas fakta-fakta, konsep-konsep, dan prinsip-prinsip kimia. Berdasarkan hal tersebut, dapat dikatakan bahwa pembelajaran kimia tidak boleh mengesampingkan proses ditemukannya konsep. Indrawati (dalam Trianto, 2007) menyatakan, bahwa suatu pembelajaran pada umumnya akan lebih efektif bila diselenggarakan melalui model-model pembelajaran yang termasuk rumpun pemrosesan informasi.

1 Corresponding author.

E-mail: ketutpadmanaba90@yahoo.co.id (I Ketut Gede Padmanaba) 
Karakteristik belajar kimia yang menuntut keterkaitan ketiga aspek makroskopik, mikroskopik dan simbolik, sering kali menyebabkan mata pelajaran kimia dianggap sebagai mata pelajaran yang sulit dipahami. Banyak hasil penelitian melaporkan bahwa kimia termasuk pelajaran yang sulit (Nakhleh, 1992). Hal ini dikarenakan sebagian besar konsep kimia mempunyai sifat abstraksi yang tinggi, salah satunya adalah pada materi sistem koloid. Sifat abstrak inilah yang selama ini sulit untuk dikontruksi oleh siswa. Oleh sebab itu, penekanan aspek mikroskopik pada siswa sangatlah penting dalam mempelajari ilmu kimia. Johnstone (2000) dan Wu, dkk. (2001) menyatakan bahwa dalam memahami kimia, pebelajar harus mampu mengaitkan tiga aspek kajian kimia, yaitu makroskopik, mikroskopik, dan simbolik. Kajian mikroskopik merupakan jembatan untuk bisa memahami kajian kimia secara makroskopik (observable) dan simbolik (notasi kimia).

Berdasarkan hal tersebut, dalam mengajarkan materi sistem koloid kepada siswa hendaknya diarahkan atau didorong pada pendekatan inkuiri (NRC, 2002). Hal ini dikarenakan pembelajaran dengan pendekatan ini memiliki keunggulan dalam pengembangan pemahaman mendalam dan keterampilan berpikir siswa yang diperlukan dalam memecahkan masalah. Temuan tentang penggunaaan pendekatan inkuiri dalam pembelajaran telah banyak dilakukan, diantaranya oleh So \& Kong (2007) menemukan bahwa penggunaan pendekatan inkuri dalam pembelajaran dapat meningkatkan pemahaman siswa.

Walaupun penggunaan pendekatan inkuiri dalam pembelajaran dapat meningkatkan pemahaman siswa, namun dalam pelaksanaannya terdapat beberapa kendala yang menghambat implementasi pembelajaran menggunakan pendekatan inkuiri. Kirna, dkk. (2007) mengemukakan bahwa kendala teknis sering dijadikan alasan guru untuk tidak menerapkan pembelajaran menggunakan pendekatan inkuiri. Sanjaya (2009) juga mengemukakan ada hambatan kultural dan politik dalam implementasi pendekatan inkuiri dalam pendidikan nasional, seperti keyakinan guru bahwa inkuiri tidak mungkin bisa dilaksanakan karena sulit untuk mengubah pola belajar siswa yang cenderung menerima.

Keberadaan Teknologi Informasi dan Komunikasi (TIK) atau Information and Communication Technology (ICT) merupakan salah satu solusi yang dapat digunakan untuk menciptakan material belajar yang dapat mendukung proses pembelajaran menggunakan pendekatan inkuiri. Media pembelajaran berbantuan komputer dapat dirancang untuk menyajikan berbagai aspek kimia, seperti aspek makroskopik, mikroskopik dan simbolik. Hal ini dikarenakan pada media pembelajaran berbantuan komputer, unsur-unsur seperti video, bunyi, teks, grafik dan animasi dapat dikemas menjadi satu. Penggunaan media berbantuan komputer dalam pembelajaran memiliki keunggulan karena dapat menyajikan simulasi aspek statik dan dinamik dari proses kimia dan dapat memberikan interaksi dua arah yang dikemas dalam bentuk interaktif komputer. Selain itu keberadaan media pembelajaran berbantuan komputer dapat menyajikan proses kimia yang cukup berbahaya dan/atau sangat mahal apabila dilakukan praktek langsung oleh siswa. Media pembelajaran berbasis komputer juga dapat membantu guru mengemas pembelajaran dengan menarik dan meningkatkan hasil belajar dan aktivitas belajar siswa. Dengan demikian, keberadaan multimedia sangat potensial dimanfaatkan untuk mendukung pembelajaran kimia yang menekankan pada aspek mikroskopik dalam pembelajaran menggunakan pendekatan inkuiri.

Beberapa penelitian berkaitan dengan penggunaan multimedia telah banyak dilakukan, diantaranya oleh Kirna (2010) pada pemahaman dan aplikasi konsep kimia pada siswa SMP dengan menggunakan hypermedia. Hasil penelitian menyimpulkan bahwa pemahaman konsep kimia siswa SMP kelas VII yang menggunakan hypermedia lebih tinggi dibandingkan dengan yang menggunakan nonhypermedia. Selain itu, penelitian yang sudah dilakukan oleh Rahmawati (2006), Sirodjuddin (2007), dan Pusparini (2009) juga menemukan bahwa pembelajaran berbantuan komputer dapat meningkatkan hasil belajar dan aktivitas belajar siswa.

Pengembangan media pembelajaran yang dapat menyajikan keterkaitan antara aspek mikroskopik, makroskopik dan simbolik serta aspek statik dan dinamik partikel sangat diperlukan dalam menunjang proses belajar mengajar. Tujuan dari penelitian pengembangan ini adalah untuk menghasilkan produk berupa media pembelajaran interaktif berbantuan komputer pada topik bahasan sistem koloid. Selain itu tujuan khusus dari penelitian pengembangan ini adalah: 1) mendeskripsikan rancang bangun media pembelajaran kimia interaktif sistem koloid berbantuan komputer; 2) mendeskripsikan penilaian dan masukan ahli (materi/isi dan media), serta praktisi terhadap pengembangan media pembelajaran kimia interaktif sistem koloid berbantuan kompter untuk siswa SMA; dan 3) mendeskripsikan tanggapan siswa terhadap media pembelajaran kimia interaktif sistem koloid berbantuan komputer. 


\section{Metode}

Penelitian pengembangan ini terdiri dari dua tahap pokok, yaitu 1) tahap pembuatan prototipe multimedia pembelajaran interaktif (tahap I), 2) tahap validasi dan uji coba produk (tahap II). Tahap pembuatan prototipe multimedia pembelajaran interaktif menggunakan model pengembangan menurut Luther yang terdiri dari tahap concept, design, meterial collecting, assembly, testing dan distribution. Sementara itu, tahap validasi dan uji coba produk pada penelitian dan pengembangan ini mengadaptasi model pengembangan Dick and Carey (2001), dimana dilakukan evaluasi formatif berupa validasi oleh ahli materi/isi, media dan praktisi serta uji perorangan dan uji kelompok kecil oleh siswa.

Desain uji coba produk dilakukan dengan rancangan sebagai berikut. 1) Prototipe media yang telah dibuat direview oleh ahli isi, ahli media serta praktisi kemudian dianalisis dan direvisi, 2) dilakukan uji perorangan terhadap produk yang telah direvisi kemudian dianalisis dan direvisi, 3) hasil revisi pada uji perorangan kemudian dilanjutkan dengan uji kelompok kecil, hasil dari uji kelompok kecil kemudian dianalisis dan direvisi sehingga dihasilkan produk akhir.

Subjek validasi dan uji coba produk pada penelitian pengembangan ini adalah 1 orang dosen kimia di Jurusan Pendidikan Kimia UNDIKSHA sebagai ahli isi, 1 orang dosen dari Jurusan Teknologi Pendidikan UNDIKSHA sebagai ahli media, 3 orang siswa kelas XI SMAN 2 Singaraja untuk uji coba perorangan dan 20 orang siswa kelas XI SMAN 2 Singaraja untuk uji coba kelompok kecil.

Data penelitian terdiri atas: 1) Data konsep pada topik bahasan sistem koloid, 2) data deskrispsi suasana pembelajaran di sekolah, 3) skor penilaian media pembelajaran interaktif oleh ahli isi, ahli media dan praktisis, serta 4) tanggapan siswa terhadap media pembelajaran interaktif. Teknik pengumpulan data yang digunakan adalah daftar analisis isi, angket analisis kebutuhan, rubrik penilaian media pembelajaran interaktif serta angket tanggapan siswa.

Data penilaian dari ahli isi, ahli materi dan praktisis dijumlahkan dan dirata-ratakan, hasilnya kemudian dikelompokkan ke dalam kriteria penilaian. Kriteria penilaian media pembelajaran interaktif dapat dilihat pada tabel 1 berikut.

Tabel 1. Kriteria Penilaian Media Pembelajaran Interaktif

\begin{tabular}{ll}
\hline Interval Skor & Kriteria \\
\hline $\mathrm{Xi}+1,5 \mathrm{Sdi} \leq \mathrm{X}$ & Sangat baik \\
$\mathrm{Xi}+0,5 \mathrm{Sdi} \leq \mathrm{X}<\mathrm{Xi}+1,5 \mathrm{Sdi}$ & Baik \\
$\mathrm{Xi}-0,5 \mathrm{Sdi} \leq \mathrm{X}<\mathrm{Xi}+0,5 \mathrm{Sdi}$ & Cukup baik \\
$\mathrm{Xi}-1,5 \mathrm{Sdi} \leq \mathrm{X}<\mathrm{Xi}-0,5 \mathrm{Sdi}$ & Kurang baik \\
$\mathrm{X}<\mathrm{Xi}-1,5 \mathrm{Sdi}$ & Sangat tidak baik \\
\hline
\end{tabular}

Indikator keberhasilan produk yang dibuat dapat ditentukan dari hasil analisis validasi oleh ahli isi, ahli media, praktisi serta respon siswa yang dilakukan secara kualitatif. Apabila hasil validasi yang dilakukan oleh ahli menunjukkan kriteria baik atau sangat baik serta hasil uji keterbacaan dan data hasil tanggapan siswa memberikan hasil yang baik maka produk yang dihasilkan dapat dikatakan berhasil. Sementara itu, apabila produk yang dihasilkan memperoleh validasi sangat tidak baik, kurang baik atau cukup baik maka produk yang dihasilkan dapat dikatakan tidak memenuhi indikator keberhasilan (produk yang dihasilkan gagal).

\section{Hasil dan pembahasan Hasil}

Empat jenis data utama yang dikumpulkan pada penelitian dan pengembanagan ini adalah: 1) data analisis konsep pada topik bahasan sistem koloid, 2) data deskripsi suasana pembelajaran di sekolah, 3) skor penilaian media pembelajaran oleh ahli isi, ahli media dan praktisis, serta 4) tanggapan siswa terhadap media pembelajaran interaktif.

Analisis konsep pada topik sistem koloid dilakukan merujuk pada klasifikasi konsep menurut Herron, klasifikasi konsep menurut Herron terdiri dari label konsep, definisi konsep (konsepsi), jenis konsep, atribut (terdiri dari atribut kritis dan variabel), posisi konsep (terdiri dari superordinat, kordinat dan subordinat) serta contoh dan non contoh. Konsep-konsep yang terdapat pada topik bahasan sistem koloid yaitu fase terdispersi, fase pendispersi, sistem koloid, sol, busa, emulsi, aerosol, koloid liofil, koloid liofob, efek Tyndall, gerak Brown, koagulasi, adsorpsi, elektroforesis, dialisis, koloid pelindung, emulgator, dispersi, kondensasi, peptisasi, dispersi dengan cara busur Bredig, dispersi secara mekanik, kondensasi dengan reaksi redoks, kondensasi dengan reaksi hidrolisis, serta kondensasi dengan reaksi substitusi. 
Data deskripsi suasana pembelajaran di sekolah dibedakan menjadi empat yakni data yang merupakan potret pembelajaran, data tentang sumber belajar yang digunakan, data motivasi belajar siswa dan data yang merupakan masukan terhadap pembuatan media pembelajaran kimia interaktif. Data-data tersebut dapat dilihat pada tabel-tabel berikut.

Tabel 2. Potret Pembelajaran di Sekolah

\section{No. Potret Pembelajaran yang}

1. Cara mengajar guru kimia yang paling sering digunakan dalam mengajar topik sistem koloid adalah diskusi kelompok dan eksperimen di laboratorium kemudian siswa membuat laporan praktikum serta cara mengajar dengan menjelaskan langsung di depan kelas dengan menulis di papan dan guru menyuruh siswa untuk melakukan diskusi kelompok.

2. Aspek yang sulit dipahami siswa dalam mempelajari topik sistem koloid adalah koloid liofob dan liofil dan pembuatan koloid.

3. $66,6 \%$ guru menyatakan pernah mengkaitkan aspek makroskopik dan mikroskopik dalam mengajar topik sistem koloid kepada siswa.

4. Dalam mengajar topik sistem koloid, guru memberikan kegiatan praktikum kepada siswa pada subtopik pembuatan koloid dan sifat-sifat koloid.

5. Alokasi waktu yang diperlukan dalam mengajar topik bahasan sistem koloid kepada siswa adalah 3 kali pertemuan (6 x 45 menit).

6. Contoh yang sering digunakan dalam mengajarkan topik sistem koloid adalah jelly, busa sabun, kabut, batu apung.

7. $66,6 \%$ siswa menyatakan buku pegangan yang digunakan sangat membantu dalam mempelajari topik sistem koloid.

8. $66,6 \%$ siswa menyatakan guru tidak pernah memanfaatkan media dalam pembelajaran kimia.

\section{Tabel 3. Sumber Belajar yang Digunakan}

No. Sumber Belajar yang Digunakan

1. Buku-buku pegangan yang digunakan guru sudah cukup memadai, berdasarkan jawaban yang diberikan 6 orang guru kimia (100\%) menyatakan buku pegangan yang digunakan sangat membantu dalam mengajar topik sistem koloid.

2. Media yang sering digunakan dalam mengajar topik sistem koloid adalah contoh nyata $(100 \%)$, gambar (50\%), komputer yakni video dan visualisasi $(33,3 \%)$ serta bagan dan peta konsep (16,7\%).

3. Buku pegangan dan LKS yang digunakan oleh siswa antara lain buku kimia penerbit Grafindo, buku kimia penerbit Esis, LKS Kreatif Kimia untuk SMA/MA kelas XI.

\section{Tabel 4. Motivasi Belajar Siswa}

No. Motivasi Belajar Siswa

1. $66,6 \%$ guru menyatakan antusiasme siswa dalam pembelajaran menggunakan multimedia adalah antusias tapi kurang partisipatif.

2. $66,6 \%$ siswa menyatakan buku pegangan yang digunakan sangat membantu dalam mempelajari topik sistem koloid.

3. $88,9 \%$ siswa menyatakan senang apabila guru memanfaatkan multimedia dalam pembelajaran di kelas.

4. $88,9 \%$ siswa menyatakan penggunaan TIK dalam proses pembelajaran mempermudah dan memperkuat pengetahuan siswa dalam memahami konsepkonsep kimia.

Tabel 5. Masukan Guru terhadap Pengembanagan Media Pembelajaran Interaktif Kimia Koloid

\section{No. Masukan Guru terhadap Pengembangan Media Pembelajaran} Interaktif Kimia Koloid

1. Dalam mengajar topik sistem koloid kepada siswa hendaknya perlu disajikan keterkaitan antara aspek makroskopik dan mikroskopik.

2. $83,3 \%$ guru menyarankan agar media pembelajaran kimia interaktif dibuat secara induktif, dimana contoh-contoh dikemukakan terlebih dahulu kemudian barulah diberi simpulan tentang konsep tersebut. 
3. Untuk membuat siswa lebih tertarik mempelajari materi sistem koloid, guru menyarankan agar siswa diberikan contoh permasalahan kontekstual yang mungkin mereka alami terkait dengan materi yang dibahas.

4. Jenis media yang diinginkan guru pada topik sistem koloid agar memudahkan penyampaian materi kepada siswa adalah media pembelajaran yang menampilkan kejadian/fenomena kimia sekitar kita (100\%), menyajikan aspek mikroskopik $(100 \%)$, menyajikan video (83,3\%), dan menyajikan simulasi $(66,6 \%)$.

Selain diperoleh data analisis konsep dan data deskripsi suasan pembelajaran, pada tahap concept juga dirumuskan indikator pembelajaran. Indikator yang telah dirumuskan adalah sebagai berikut. 1) Menjelaskan pengertian koloid, 2) menentukkan perbedaan larutan, koloid dan suspensi, 3) mengidentifikasi jenis koloid berdasarkan fase terdispersi dan fase pendispersi, 4) menjelaskan sifat-sifat koloid (efek Tyndall, gerak Brown, elektroforesis, adsorpsi, koagulasi), 5) menjelaskan peranan koloid dalam kehidupan sehari-hari, 6) menjelaskan pengertian koloid liofil dan liofob, 7) menentukan perbedaan koloid liofil dan liofob, 8) menjelaskan cara pembuatan koloid dengan cara dispersi dan kondensasi, dan 9) menjelaskan proses pemurnian koloid dengan cara dialisis.

Pada tahap desain dilakukan pembuatan RPP, maping program, merancang kerangka media pembelajaran interaktif serta pembuatan storyboard media pembelajaran interaktif. Maping program yang dimaksud berupa rincian indikator sistem koloid yang akan ditampilkan dalam media pembelajaran agar sesuai dengan SK/KD yang telah ditetapkan.

Pada tahap material collecting dilakukan pengumpulan bahan-bahan yang diperlukan di dalam pembuatan media pembelajaran kimia interaktif.

Tahap assembly dilakukan dengan merakit materi-materi penyusun media pembelajaran agar menjadi satu kesatuan yang utuh. Storyboard yang telah dibuat sebelumnya pada tahap design, pada tahap assembly direalisasikan menjadi sebuah tampilan rinci dengan menggunakan Macromedia Flash 8.0.

Tahap testing dilakukan dengan menjalankan aplikasi di komputer yang berbeda. Pengembang tidak menemukan kendala pada proses pembacaan data oleh CD-ROM (Read-Only Memory) komputer yang berbeda sehingga dapat dikatakan media pembelajaran kimia interaktif sistem koloid yang dibuat telah melewati tahap testing.

Tahap distribution dilakukan dengan melakukan pengemasan dan penggandaan produk.

Pada tahap validasi dan uji coba produk diperoleh data penilaian dari ahli isi, ahli media dan praktisi terhadap media pembelajaran interaktif yang dibuat, selain itu diperoleh data tanggapan siswa.

Skor rata-rata hasil penilaian yang diberikan oleh ahli isi adalah 4,76 atau dapat dikatakan berada pada kategori sangat baik. Penilaian yang diberikan oleh ahli isi/materi meliputi aspek kelayakan isi, komponen penyajian serta kualitas media.

Skor rata-rata dari hasil penilaian yang diberikan oleh ahli media adalah 4,19 atau dapat dikatakan berada pada kategori baik. Penilaian yang diberikan oleh ahli media meliputi aspek penggunaan produk dan kualitas media.

Skor rata-rata dari hasil penilaian yang diberikan oleh praktisi adalah 3,82 atau dapat dikatakan berada pada kategori baik. Penilaian yang diberikan oleh praktisi berdasarkan kesesuaian beberapa aspek seperti: 1)indikator pencapaian kompetensi, 2) isi pembelajaran, 3) kualitas motivasi, 4) bahasa, 5) evaluasi pembelajaran, 6) kualitas media, 7) pemberian kesempatan belajar, 8) efisiensi media, 9) fleksibilitas media, serta 10) dampak bagi siswa.

Hasil uji perorangan menunjukkan bahwa media pembelajaran kimia interaktif sistem koloid yang dibuat mendapat respon baik dari siswa dimana skor rata-rata tanggapan siswa adalah 4,46. Tanggapan yang diberikan oleh siswa dikaji dari beberapa aspek meliputi aspek pemberian kesempatan belajar, kualitas motivasi, materi pembelajaran, efisiensi media, fleksibilitas media, pembelajaran serta dampak bagi siswa.

Hasil dari uji kelompok kecil menunjukkan bahwa respon yang diberikan siswa dapat digolongkan ke dalam kategori baik. Kategori baik ini di dadasarkan skor rata-rata respon siswa yaitu 4,44. Aspek yang dikaji pada uji kelompok kecil sama dengan aspek pada uji perorangan.

\section{PEMBAHASAN}

Produk yang dikembangkan dalam penelitian ini adalah perangkat pembelajaran berupa CD (Compact Disc) media pembelajaran kimia interaktif topik bahasan sistem koloid. Media pembelajaran kimia interaktif topik bahasan sistem koloid dibuat dengan memanfaatkan software macromedia flash 8.0. Pembuatan media pembelajaran kimia interaktif ini merujuk pada Peraturan 
Menteri Pendidikan Nasional No. 22 Tahun 2006 tentang Standar Isi. Standar Kompetensi (SK) untuk topik bahasan sistem koloid adalah menjelaskan sistem dan sifat koloid serta penerapannya dalam kehidupan sehari-hari. Standar Kompetensi tersebut terdiri dari dua Kompetensi Dasar (KD) yaitu pembuatan berbagai jenis sistem koloid dengan bahan di sekitar serta pemahaman akan pengelompokkan dan penerapan sistem koloid dalam kehidupan sehari-hari.

Media pembelajaran kimia interaktif yang dikembangkan dirancang mengikuti pendekatan inkuiri dalam mendukung pembelajaran kimia topik bahasan sistem koloid. Media pembelajaran kimia interaktif ini menampilkan fenomena-fenomena alam yang berkaitan dengan sub topik yang akan dibahas dan dilengkapi dengan kajian mikroskopik seperti simulasi atau animasi untuk memvisualisasikan aspek-aspek mikroskopik. Pendekatan inkuiri digunakan dalam pengembangan multimedia pembelajaran kimia interaktif sistem koloid ini dikarenakan pendekatan ini memiliki keunggulan dalam pengembangan pemahaman mendalam dan keterampilan berpikir (strategi kognitif) yang diperlukan dalam memecahkan masalah (NRC, 2002). Sebagai payung dari pendekatan induktif, inkuiri mencakup berbagai model atau strategi pembelajaran. Pembelajaran yang berangkat dari kasus (cases atau problems), memberikan penekanan pada pertanyaan (questioning), penyelidikan (investigating), dan penemuan (discovering) adalah pembelajaran menggunakan pendekatan inkuiri. Aspek inkuiri yang terdapat pada media pembelajaran kimia interaktif sistem koloid ini dapat dilihat pada menu pembelajaran.

Pembelajaran yang dirancang pada media pembelajaran interaktif sistem koloid selalu diawali dengan fenomena-fenomena kontekstual terkait dengan sub topik yang akan dibahas kemudian dilanjutkan dengan memberikan pertanyaan-pertanyaan terkait sebelum memberikan kesimpulan terhadap sub topik yang dibahas. Salah satu contohnya adalah pada pembelajaran 1 dengan indikator menentukan perbedaan larutan, koloid dan suspensi dimana ditampilkan video penyaringan larutan, koloid dan suspensi. Siswa terlebih dahulu mengamati dengan cermat video penyaringan tersebut, kemudian diberikan tabel interaktif yang harus dijawab oleh siswa terkait dengan perbedaan antara larutan, koloid, dan suspensi. Contoh tersebut merupakan salah satu aspek inkuiri yang terdapat pada media pembelajaran kimia interaktif sistem koloid yang dikembangkan.

Selain menampilkan fenomena-fenomena alam yang kontekstual, media pembelajaran kimia interaktif yang dikembangkan memiliki beberapa karakteristik. Karakteristik dari media pembelajaran kimia interaktif sistem koloid adalah sebagai berikut. Pertama, media pembelajaran yang dibuat terdiri dari beberapa bagian, seperti bagian awal atau home, tentang media, kompetensi, pembelajaran, materi, evaluasi, pengembang dan referensi. Kedua, menyajikan aspek makroskopik, mikroskopik, dan simbolik. Ketiga, menyajikan simulasi statik maupun dinamik. Keempat, memberikan interaksi dua arah yang memungkinkan siswa untuk dapat memasukkan jawaban dan kemudian diberikan balikan oleh media pembelajaran kimia interaktif.

Hasil validasi oleh ahli isi/materi menunjukkan bahwa media pembelajaran kimia interaktif yang dibuat memenuhi kategori sangat baik dimana skor rata-rata penilaian yang diberikan adalah 4,76. Penilaian yang diberikan oleh ahli isi/materi meliputi aspek kelayakan isi, komponen penyajian serta kualitas media. Dari segi kelayakan isi, ahli isi/materi menyatakan bahwa konsistensi isi dari media pembelajaran kimia interaktif yang dikembangkan sudah sesuai. Setiap indikator yang dirancang sudah dilengkapi dengan konten-konten pendukung yang ditampilkan dalam media pembelajaran kimia interaktif sistem koloid. Misalnya pada indikator menjelaskan pengertian koloid, konten pendukung yang disajikan pada media pembelajaran kimia interaktif yaitu 1) fenomena penghamburan sinar yang dilewatkan pada koloid dan larutan, animasi mikroskopik penghamburan cahaya yang dilewatkan pada suatu koloid, 2) animasi mikroskopik yang menunjukkan ukuran diameter fase terdispersi dari sistem koloid, serta 3) gambar koloid belerang dalam air yang dilengkapi dengan animasi mikroskopik fase terdispersi dan fase pendispersi. Selain menilai dari segi kelayakan isi, ahli materi/isi juga memberikan penilaian dari segi komponen penyajian yang meliputi sistematika penyajian pembelajaran serta kesesuaian dalam mendukung pembelajaran menggunakan pendekatan inkuiri.

Penilaian dari segi tampilan media dan bahasa dilakukan oleh ahli media, tampilan dan bahasa yang digunakan dalam media pembelajaran kimia interaktif yang dikembangkan dinilai kesesuaiannya. Berdasarkan hasil validasi oleh ahli media tampilan media dan bahasa yang digunakan dalam media pembelajaran kimia interaktif secara umum dapat dikatakan sesuai. Skor rata-rata dari hasil penilaian yang diberikan oleh ahli media adalah 4,19 atau berada dalam kategori baik. Penilaian dari ahli media juga merupakan penilaian dari aspek kerja program atau kelancaran media pembelajaran ketika dioperasikan. Berdasarkan penilaian ini, dapat dikatakan bahwa media pembelajaran kimia interaktif sistem koloid ini lancar bila dilihat dari aspek kelancaran kinerja program. 
Validasi yang dilakukan oleh praktisi bertujuan untuk menguji media pembelajaran yang dibuat dan untuk memperoleh masukan praktisi dari segi pembelajaran dan kualitas media. Apabila dilihat dari penilaian praktisi (guru), media pembelajaran kimia interaktif sistem koloid yang dikembangkan dapat dikatakan layak digunakan di dalam pembelajaran. Penilaian ini didasarkan atas skor rata-rata penilaian guru yakni 3,82 atau berada dalam kategori baik. Kategori baik berarti semua aspek yang berada pada kriteria penilaian telah sesuai. Kesesuaian ini dilihat dari beberapa aspek meliputi: 1) indikator pencapaian kompetensi, 2) isi pembelajaran, 3) kualitas motivasi, 4) bahasa, 5) evaluasi pembelajaran, 6) kualitas media, 7) pemberian kesempatan belajar, 8) efisiensi media, 9) fleksibilitas media, serta 10) dampak bagi siswa.

Media pembelajaran kimia interaktif sistem koloid yang dirancang juga dilakukan uji coba secara perorangan dan juga uji kelompok kecil. Uji coba perorangan ini dilakukan untuk mengetahui dan menganalisis tanggapan siswa terhadap media pembelajaran kimia interaktif sistem koloid yang dikembangkan. Hasil uji perorangan menunjukkan bahwa media pembelajaran kimia interaktif sistem koloid yang dibuat mendapat respon baik dari siswa dimana skor rata-rata tanggapan siswa adalah 4,46. Tanggapan yang diberikan oleh siswa dikaji dari beberapa aspek meliputi aspek pemberian kesempatan belajar, kualitas motivasi, materi pembelajaran, efisiensi media, fleksibilitas media, pembelajaran serta dampak bagi siswa. Dari aspek pemberian kesempatan belajar, fleksibilitas media, serta dampak bagi siswa, hasil uji perorangan menunjukkan bahwa respon yang diberikan oleh siswa terkait ketiga aspek tersebut adalah sangat baik. Hal ini berarti bahwa media pembelajaran kimia interaktif sistem koloid dapat memberikan kesempatan belajar yang luas bagi siswa, media pembelajaran kimia interaktif yang dibuat bersifat fleksibel (dapat digunakan secara perseorangan atau kelompok), serta memacu siswa untuk belajar. Dari aspek kualitas motivasi dan aspek pembelajaran, hasil uji perorangan menunjukkan kategori baik. Kategori baik berarti media pembelajaran kimia interaktif yang dibuat memiliki potensi untuk meningkatkan motivasi belajar siswa. Sudjana \& Rivai (dalam Arsyad, 2011) menyatakan bahwa penggunaan media dalam kegiatan pembelajaran membuat pembelajaran menjadi lebih menarik perhatian siswa sehingga motivasi belajar akan tinggi. Kategori baik pada aspek pembelajaran menunjukkan bahwa organisasi isi pembelajaran pada media pembelajaran kimia interaktif yang dibuat telah sesuai. Sementara itu, dari aspek efisiensi media respon yang diberikan siswa dapat di golongkan ke dalam kategori cukup baik. Hal ini berarti menurut siswa efisiensi dari media pembelajaran kimia interaktif yang dibuat cukup efisien.

Setelah dilakukan uji coba produk secara perorangan, kemudian dilanjutkan dengan uji kelompok kecil. Hasil dari uji kelompok kecil menunjukkan bahwa respon yang diberikan siswa dapat digolongkan ke dalam kategori baik. Kategori baik ini di dadasarkan skor rata-rata respon siswa yaitu 4,44. Aspek yang dikaji pada uji kelompok kecil sama dengan aspek pada uji perorangan.

Berdasarkan uji coba produk yang telah dilakukan baik uji coba perorangan maupun uji coba kelompok kecil maka media pembelajaran kimia interaktif sistem koloid yang dibuat dapat dikatakan mendapat respon baik dari siswa sehingga layak digunakan untuk memfasilitasi belajar siswa.

Media pembelajaran kimia interaktif sistem koloid yang dikembangkan memiliki beberapa keunggulan seperti interaktivitas media, penekanan aspek kimia mikroskopik serta penekanan pada visualisasi. Dari segi interaktivitas, media pembelajaran kimia interaktif sistem koloid memberikan interaksi dua arah yang memungkinkan siswa untuk dapat memberikan jawaban dan kemudian diberikan balikan oleh media pembelajaran kimia interaktif. Multimedia secara tidak langsung dapat memaksa pengguna untuk berinteraksi dengan materi. Interaksi ini bervariasi dari yang paling sederhana hingga yang bersifat kompleks. Interaksi sederhana misalnya pengguna harus mengklik tombol untuk berpindah halaman atau memasukkan jawaban dari suatu latihan, kemudian komputer merespons dengan memberikan jawaban benar melalui umpan balik (feedback).

Dari segi penekanan aspek mikroskopik, media pembelajaran kimia interaktif yang dikembangkan sangat menekankan pada aspek mikroskopik. Hal ini dikarenakan sebagian besar konsep kimia mempunyai sifat abstraksi yang tinggi, salah satunya adalah pada materi sistem koloid. Sifat abstrak inilah yang selama ini sulit untuk dikontruksi oleh siswa. Oleh sebab itu, penekanan aspek mikroskopik pada siswa sangatlah penting dalam mempelajari ilmu kimia. Johnstone (2000) dan Wu, dkk. (2001) menyatakan bahwa dalam memahami kimia, pebelajar harus mampu mengaitkan tiga aspek kajian kimia, yaitu makroskopik, mikroskopik, dan simbolik. Kajian mikroskopik merupakan jembatan untuk bisa memahami kajian kimia secara makroskopik (observable) dan simbolik (notasi kimia) (Stieff dalam Kirna 2010).

Selain itu, keunggulan media pembelajaran kimia interaktif sistem koloid yang dikembangkan adalah menekankan pada pentingnya aspek visualisasi. Terdapat beberapa bukti empiris yang memperlihatkan bahwa secara umum memory untuk gambar lebih baik daripada 
memory untuk kata (verbal). Temuan ini menegaskan bahwa visualisasi (imagery) merupakan komponen multimedia yang penting dalam pembelajaran. Kirna (2010) merangkum beberapa temuan ahli berkaitan dengan pentingnya visualisasi dalam pembelajaran seperti yang diungkapkan oleh Gilbert, Smaldino, dan Arend. Visualisasi mempunyai peran sentral dalam pembelajaran, utamanya sains (Gilbert, 2005). Potensi visualisasi dalam belajar dikemukakan oleh Smaldino, dkk. (2005: 81) bahwa "... some students learn more readily through visual imagery, and even those who are verbal learners need visual supports to grasp certain types of concepts". Arend (2004: 345) mengemukakan potensi visualisasi dalam pembelajaran dengan ungkapan "A picture is worth of a thousand words when teaching a difficult concept to students".

Visualisasi memiliki peran penting dalam proses pembelajaran (Smaldino, dkk., 2005), yaitu: 1) menyediakan referensi ide yang kongkrit, 2) memotivasi siswa dengan cara meningkatkan atensi, mempertahankan atensi, dan membangkitkan respon emosi, 3) menyederhanakan informasi yang sulit dipahami, 4) membantu mengorganisasi materi dengan mengilustrasikan hubungan antar elemen berupa diagram, dan 5) memberikan saluran ganda atau informasi yang multimodalitas sehingga memudahkan pemahaman. Visualisasi, utamanya yang berbasis komputer, banyak digunakan dalam pembelajaran yang menekankan pemahaman siswa (Roblyer, dalam Kirna 2010).

Berdasarkan beberapa keunggulan tersebut, maka media pembelajaran kimia interaktif sangat potensial dimanfaatkan untuk mendukung pembelajaran kimia yang menekankan pada aspek mikroskopis. So \& Kong (2007) melaporkan bahwa penggunakan multimedia dalam pembelajaran menggunakan pendekatan inkuiri dapat meningkatkan hasil belajar sains di sekolah dasar. Kirna (2010) menemukan bahwa integrasi multimedia interaktif dalam pembelajaran menggunakan pendekatan inkuiri, yaitu siklus belajar tiga fase lebih unggul dilihat dari pemahaman konsep kimia siswa SMP kelas VII dibandingkan dengan pembelajaran kimia konvensional maupun siklus belajar tiga fase tanpa bantuan multimedia. Kirna (2010) juga menemukan bahwa integrasi multimedia dalam pembelajaran menggunakan strategi siklus belajar adalah superior bagi siswa yang memiliki gaya belajar visual dan tidak menghambat siswa verbal dalam belajar kimia. Oleh karena itu, keberadaan media pembelajaran kimia interaktif sistem koloid ini diharapkan dapat membantu siswa di dalam proses pembelajaran topik bahasan sistem koloid.

\section{Simpulan dan saran}

Berdasarkan penelitian yang dilakukan dapat diberikan beberapa simpulan sebagai berikut. (1) Bakteri hasil isolasi dari tanah pertanian kubis adalah Bacillus brevis. (2) Kondisi media fermentasi untuk menghasilkan metabolit sekunder yang optimum adalah massa jerami 10 gram, kelembaban medium 70\%, dan waktu fermentasi 3 hari. (3) Metabolit sekunder dari Bacillus brevis berpotensi sebagai biopestisida. Penggunaan metabolit sekuder $100 \%$ memberikan tingkat mortalitas sebesar $66,7 \%$ dan persentase antifeedant tertinggi sebesar 37,09\%. Biopestisida dari bakteri Bacillus brevis dapat dijadikan sebagai alternatif bagi petani dalam memilih pestisida yang lebih ramah lingkungan.

\section{Daftar Rujukan}

Abedon, S. T. 2003. "Important Words and Concepts from Chapter 6, Black, 1999". Tersedia pada http://www.mansfield.ohio-state.edu/sabedon/black06.htm.

Blibech, Imen., Mohieddine Ksantini, Ikbal Chaieb, Brahim Jlassi, Ali Rhouma, Samir Jaoua, dan Sami Aifa. 2011. "Isolation of Entomopathogenic Bacillus from a Biodynamic Olive Farm and Their Pathogenicity to Lepidopteran and Coleopteran Insect Pests". Crop Protection 31 (2012) 7277. Elsevier Ltd.

Carrizales V, Rodriguez H. 1981. "Determination of Specific Growth Rate of Moulds in Semi Solid Cultures". Biotechnol. Bioeng. 1981; 23:321-333.

Centikaya, Fatos Tuba. 2002. "Isolation of Bacillus Thuringiensis and Investigation of Its Crystal Protein Genes". Desertasi. Turkey : Intitute of Technology Izmir.

Dadang dan Kanju Oshawa. 2000. "Penghambatan Aktivitas Makan Larva Plutella xylostella (L.) (Lepidoptera: Yponomeutidae) yang Diperlakukan Ekstrak Biji Swietenia mahogany JACQ (Meliaceae)". Bulletin of Plant Pests and Diseases, Vol. 12 No. 1: 27-32l.

Dalimarta, Setiawan. 2001. "Atlas Tumbuhan Obat di Indonesia". Niaga Swadaya: Jakarta.

Djunaedy, A. 2009. "Biopestisida sebagai Pengendali Organisme Pengganggu Tanaman (OPT) yang Ramah Lingkungan". Jurnal Embryo vol.6 no.1:88-95.

Dulmage, T., A.A. Yousten, S. Singer, dan L.A. Lacey. 1990. "Guidelines for Production Bacillus thuringiensis H-14 and Bacillus sphaericus". 
Ebrahimi, Saloomeh dan Abbass Akhavan Sepahi. 2008. "Exopolysacarid Production by Strain of Brevibacillus brevis: Potential Applications in the Treatment of Hydrocarbons Pollution and Use in Microbial Enhance Oil Recovery (MEOR)". Makalah disajikan dalam $2^{\text {nd }}$ WSEAS Int. Conf. on Management, Marketing, and Finances. Islamic Azad University, Iran.

Enturk, Omer, Vedat Ekero Lu, dan Ahmet Koc Yavuz Kalkan. 2004. "Antifeedant and Toxicity Effects of Some Plants Extracts on Yponomeuta malinellus Zell. (Lep: Yponomeutidae). Journal of Plant Protection Research, Vol. 44 No. 3.

Eyhorn, F, M Heeb, G Weidmann. 2002. "IFOAM training manual on organic agriculture in the tropics". International Federation of Organic Agriculture Movements (IFOAM).

Farzana, K., S. N. Hussain Shah, F. B. Butt, dan S. B. Awan. 2005. "Biosynthesis of Bacitracin in SolidState Fermentation by Bacillus licheniformis using Defatted Oil Seed Cakes as Substrate". Pakistan Journal of Pharmaceutical Sciences. Vol. 18, No.1, January 2005, pp.55-57

Gervais, P., P.A. Marechal, dan P. Molin. 1996. "Water Relation of Solid State Fermentation". Journal of Scientific and Industrial Research. 55: 343-357.

Isman, M.B., H. Matsuura, S. MacKinnon, T. Durst, G.H.N. Towers and J.T. Arnason, 1996. "Phytochemistry of the meliaceae: So many terpenoids, so few insecticides". Recent Adv. Phytochem. 30: 155-178.

Jamil, Bushra, Frank Hasan, A. Hameed, Safia Ahmed. 2007. "Isolation of Bacillus subtilis MH-4 from Soil and Its Potential of Polipeptide Antibiotic Production". Journal of Pharm Science. Vol. 20, hal. 26-31.

Jaquet, Francoise, R. Hutter, P. Luthy. 1986. "Specificity of Bacillus thuringiensis Delta-Endotoxin". Applied and Environmental Microbiology. Mar. 1987. p. 500-504. Vol. 53, No. 3.

Kuberan, T., S. Sangaralingam dan V. Thirumalai Arasu. 2010. "Isolation dan Optimization of Protease Producing Bacteria from Halophilic Soil”. Journal of Biosciences Research, Vol. 1 No. 3: 163174.

Makal, Henny V. G. dan Deflly A. S. Turang. "Pemanfaatan Ekstrak Kasar Batang Serai untuk Pengendalian Larva Crocidolomia Binotalis zell. Pada Tanaman Kubis”. 2011. Eugenia. Vol. 17 No 1.

Maurya, P. Davendra, Dhananjay Singh, Durgesh Pratap dan Jitendra P. Maurya. 2012. “Optimization of Solid State Fermentation Conditions for the Production of Cellulase by Trichoderma reesei. J. Environ. Biol. 33,5-8.

Meyrial, V., Delgenes, J. P., Moletta, R., dan Navarro, J. M. 1991. "Xylitol Production by Candida guilliermondii: Fermentation Behavior". Bio-technol. Lett. 13: 281-286.

Novizan. 2005. “Membuat dan Memanfaatkan Pestisida Ramah Lingkungan”. Agro Media Pustaka. Jakarta. 1-12.

Pandey A. "Recent Developments in Solid-State Fermentation". Process Biochem. 1992; 27:109-116.

Pattahudin. 2005. "Uji Beberapa Konsentrasi dan Resistensi Beauveria bassiana vuillemin (Deteromicetes: Monoliccieae) terhadap Mortalitas Spodoptera exigua hubner (Lepidoptera : Noctuidea) pada Tanaman Bawang Merah". Makalah disajikan dalam Prosiding Seminar Ilmiah dan Pertemuan Tahunan PGJ dan PFJ XV. Universitas Hassanudin, Sulawesi Selatan.

Prijono, D. 2003. "Teknik Ekstraksi, Uji Hayati, dan Aplikasi Senyawa Bioaktif Tumbuhan". Departemen Hama dan Penyakit Tumbuhan, Fakultas Pertanian, Institut Petanian Bogor. 62 hlm.

Prior, B.A., Killian S.G., dan Preez J.C. 1989. "Fermentation of D-xyloseby the yeasts Candida shehatae

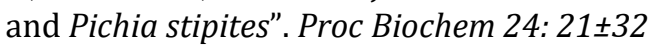

Purnamasari, Astri Wulan. 2006. "Keefektifan CRY1B dan CRY1C Bacillus thuringiensis B. terhadap Plutella xylostella L. (Lepidoptera: Yponomeutidae) dan Crocidolomia pavonana F. (Lepidoptera: Pyralidae)". Skripsi (tidak diterbitkan). Program Studi Hama dan Tumbuhan, Institut Pertanian Bogor.

Schlegel. 1986. "Features of Biotechnological Importance in Microorganisms". Tersedia pada http://www.eplantscience.com

Shen, H. S., D. B. Ni and F. Sundstøl. 1998. "Studies on untreated and urea-treated rice straw from three cultivation seasons: 1 . Physical and chemical measurements in straw and straw fractions". Anim. Feed Sci. Technol. 73:243-261.

Singh, Manoj, Kumar Saurav, Neha Srivastava dan Krishnan Kannabiran. 2010. "Lipase Production by Bacillus subtilis OCR-4 in Solid State Fermentation Using Ground Nut Oil Cakes as Substrate”. Journal of Biological Sciences 2(4): 241-245, 2010.

Valicente, F. H., E. De Souza Tuelher, M. I. Santos Leite, F. Lyon Freire dan C. M. Vieira. 2010. "Production of Bacillus thuringiensis Biopesticide Using Commercial Lab Medium and 
Agricultural By-products as Nutrient Sources". Revista Brasileira de Milho e Sorgo. v.9, n.1, p. $1-11$

Vastrad, BM and SE Neelagund. 2012. "Optimization of Process Parameters for Rifamycin B Production under Solid State Fermentation from Amycolatopsis mediterranean MTCC 14". International Journal of Current Pharmaceutical Research, Vol 4 No. 2.

Wibisono, Hariawan. 2011. “Analisis Usaha Tani Kubis”. Skripsi (tidak diterbitkan). Fakultas Ekonomi. Universitas Diponegoro Semarang.

Widodo. 2002. "Microbiology for Foods and Industry of Animal Products". Lacticia Press.

Wiyantono, Djoko Prijono, dan Syafrida Manuwoto. 2001. "Bioaktivitas Ekstrak Biji Aglaia harmsiana Terhadap Ulat Krop Kubis, Crocidolomia binotalis". J. II. Pert. Indon. Vol. 10(1)

Yasin, Nur dan Purnomo. 2004. "Isolasi Bacillus thuringiensis dari Tanah Hutan Damar Lampung dan Uji Toksisitasnya terhadap Ulat Kubis (Plutella xylostella). Penelitian Dosen Muda. Fakultas Pertanian Universitas Lampung 